ISSN 2081-8130

DOI: $10.14746 /$ prt.2017.1.3

www.praktykateoretyczna.pl

\title{
SŁUŻBA I MILCZENIE
}

\section{CAROLYN STEEDMAN}

PRZEKLAD: KATARZYNA CZECZOT

PRZEKŁAD PRZEJRZAŁ I POPRAWIL: JĘDRZEJ BRZEZIŃSKI

\begin{abstract}
Abstrakt: Tekst jest wstępnym rozdziałem z książki Carolyn Steedman „Służąca i jej pan. Miłość i praca w Anglii wieku industrialnego" (Master and Servant. Love and Labour in the English Industrial Age). Tytułowa służąca to Phoebe Beatson, której losy Steedman rekonstruuje na podstawie dziennika jej pracodawcy - pastora Johna Murgatroyda. Zestawiając to świadectwo z innymi dokumentami życia społecznego epoki, Steedman pisze historię klasy pominięta w tradycyjnych marksistowskich historiografiach - historię kobiecej służby domowej.
\end{abstract}

Słowa kluczowe: historia społeczna, historia kobiet, służba domowa, dokument osobisty 
Oto książka o pewnej służącej i jej panu, żyjących w czasach i miejscu „powstawania angielskiej klasy robotniczej" - w przemysłowym regionie West Riding hrabstwa Yorkshire i o zmianach ich wzajemnej relacji. Obejmuje ona okres od roku mniej więcej 1785, kiedy to Phoebe Beatson rozpoczęła służbę u wielebnego Johna Murgatroyda, mieszkającego w Slaithwaite tuż pod Huddersfield, aż do pierwszej dekady kolejnego stulecia, gdy w atmosferze skandalu urodziła ona w domu pastora nieślubne dziecko. Podczas tych lat wojny, głodu, rewolucji i kontrrewolucji anglikański Bóg, któremu Murgatroyd przez całe swoje długie życie służył, głosząc wiarę, zmienił swoje oblicze i charakter, a Kościół i państwo, prawodawstwo i jurysdykcja przedefiniowały stosunek do służby, a także międzyludzkie i społeczne więzi, jakie obejmowało pojęcie „służby”. Tutaj zobaczymy tylko jeden mały skurcz bolesnych narodzin nowoczesnego społeczeństwa przemysłowego i niektóre drobne emocjonalne manipulacje dokonywane przez niezliczone jednostki stające się podmiotami nowoczesności.

Moim zamierzeniem w książce było wyjaśnienie tego, w jaki sposób opisani w niej historyczni aktorzy byli zdolni zadać kłam tak wielu wizerunkom, które im i ludziom im podobnym przypisywali zazwyczaj historycy.

Przede wszystkim zaś chciałam zrozumieć i wyjaśnić, dlaczego George Thorp odmówił poślubienia Phoebe Beatson. Ciążę, z której urodził się bękart Thorpa, nosiła ona przez wiosnę i lato 1802 roku, a sam Thorp jakimś sposobem nie uległ - dobrze znanej historyczkom i historykom angielskiej klasy robotniczej - presji kleru, urzędników od ustawy o ubogich, pracodawców, dzierżawców, właścicieli ziemskich oraz sędziów, zgodnie nalegających, by uczynił ją uczciwą kobietą i w ten sposób uwolnił parafię od ewentualnych roszczeń pieniężnych. Byli to ludzie nieczęsto spotykani, przynajmniej w dwudziestowiecznej historii społecznej, traktującej o ludziach im podobnych. Ich zachowanie i poglądy sytuowały się na zewnętrznych, ledwie widocznych krańcach krzywej dzwonowej tego, co „normalne” i często spotykane. Co więcej, Bóg, w którego wierzyli, także szedł na przekór tendencjom i pozwalał im myśleć, czuć i zachowywać się w sposób raczej sprzeczny z Jego reputacja gwaranta surowych zasad moralności i posłuszeństwa wobec praw Kościoła i państwa ${ }^{1}$.

Kiedy zaczynałam pisać, potrafiłam wyjaśnić, niemal wyczerpująco, zachowanie pracodawcy Phoebe Beatson. Wielebny John Murgatroyd (1719-1806) był przez krótki okres, w połowie osiemnastego wieku, wikarym w Almondbury i przez prawie pięćdziesiąt lat nauczycielem w Slaithwaite (jakieś pięć mil od parafii Almondbury). Gdy go spotykamy, jest już emerytem zamieszkującym osadę Lingards (tuż nad Slaithwaite, po drugiej stronie rzeki

\footnotetext{
${ }^{1}$ Pomiędzy historykami nie ma zgody w kwestii wpływu i skutków osiemnastowiecznego anglikanizmu, ale stwierdzenie Williama Gibsona, że „poziom oddania Kościołowi był [...] znacznie większy, niż historycy skłonni by byli sądzić, i osiemnasty wiek jest być może ostatnim okresem, kiedy powszechna wiara może nie podlegać dyskusji”. (Gibson 1994, 10).
} 
Colne) i perypatetycznym kaznodzieją w prawie wszystkich kościołach i kaplicach w promieniu dwudziestu mil od domu. Kiedy jego służąca Phoebe zachodzi w ciążę, w okolicach Bożego Narodzenia w 1801 roku, nie odprawia jej, nie dając jej tym samym wejść $\mathrm{w}$ znaną sentymentalną opowieść o uwiedzeniu i zdradzie. Zgodnie z zasadami (późnoosiemnastowiecznych konwencji literackich i nowoczesnej historii społecznej) powinien był oddalić ją ze służby (do czego miał zreszta prawo), złożyć ją - jako kobietę upadła - w ofierze reformatorskiej wyobraźni, pewnie nieumyślnie skazując ją na wycieranie bruku tłustych alei przemysłowego miasta (może Leeds albo Manchesteru, gdzie rozgrywało się najwięcej historii o zejściu na dno prostytucji) i na konieczność sprzedawania się, na drodze do zbawienia, humanitarnym zwierzchnikom². Nie zrobił on jednak żadnej z tych rzeczy, a jeśli wierzyć jego dziennikowi, nigdy jej również nie obwiniał, ani nie potępiał. Pozwolił jej urodzić córkę w swoim domu, a przyjmując bękarta, ochrzcił go, otoczył miłością i zapewnił mu dach nad głowa. W dzienniku zaś odnotowywał kolejne etapy rozwoju dziecka.

Umierając w 1806, zapewnił matce i córce spokojną przyszłość. I wydaje się, że istotnie żyły one z pastorem szczęśliwie, aż do czwartych urodzin Elizy Beatson.

$[\ldots]$

Phoebe Beatson nie zabiera głosu w dzienniku Murgatroyda (choć zajmuje ona w nim miejsce tak poczesne, jak zajmowała w jego życiu). Nie umiała ona również pisać. Nie miała więc możliwości napisania (i opublikowania) społecznych reportaży i satyr, tworzonych jak nie przestajemy odkrywać - przez osiemnastowieczne pokojówki ${ }^{3}$. Na początku lata 1802 roku Phoebe kilka razy stanęła przed sądem, gdzie przesłuchiwano ją w sprawie jej stanu meldunkowego i proszono o wskazanie ojca jej nienarodzonego dziecka, lecz wszelkie ślady jej pobytu w pokoju przesłuchań zostały zagubione. Ani ona, ani John Murgatroyd nie zgłosili się nigdy do lokalnego magistratu, by zweryfikować, czy nie zostały przekroczone granice ich kontraktu (umowy o prace), ani ze skarga o jego naruszenie. W sprawie Phoebe Beatson nie słyszymy więc zaskakującego, bezpośredniego głosu rozlegającego się z sędziowskich protokołów, jak choćby głos Mary Cant z Nottinghamshire, która jesienią 1785 roku oświadcza Sir Gervazemu Cliftonowi, sędziemu pokoju, że jej pracodawca traktował ją bardzo źle i uderzył w głowę, a wszystko dlatego, że gdy jej rozkazał ubrać dziecko, odpowiedziała, że „może je ubrać sam, ponieważ ona jest zajęta” (Clifton 1785, 124).

\footnotetext{
2 Więcej na temat „sentymentalnych narracji o prostytucji późnoosiemnastowiecznych humanitarnych reformatorów” zob. Taylor 2003, 242; a także Jones 1995, 41-70. Za apogeum manchesterskiej różnorodności można prawdopodobnie uznać Ruth Elizabeth Gaskell (1853). Zob. także Steedman 2000, 25-39. Jeśli chodzi o to, co prawo mówiło na temat zwalnia służących w ciąży, zob. rozdział 7 niniejszej książki.

3 Dla literaturoznawczyń osiemnastowieczne pokojówki wcale nie milcza. Zob. Landry 1990; Steedman 2005, 1-27.
} 
Dużo społecznych historyczek i historyków osiemnasto- i dziewiętnastowiecznej Anglii, potykając się na milczeniu żeńskiej służby domowej, wybierało proste rozwiązanie polegające na wyłączeniu jej z opowieści. „Nie przyglądałam się służbie domowej”, mówi Nicola Verdon, rozpatrując pracę i płace wiejskich kobiet od lat dziewięćdziesiątych osiemnastego wieku aż do współczesności; ona i wiele innych (Verdon 2002, 5). Jeśli już ktoś zajmuje się sferą służby domowej w osiemnastym wieku, zwykle reprodukuje punkt widzenia historyczek i historyków późniejszych okresów: pokojówce źle się płaci, ma niski status, jej prace najlepiej opisuje słowo „zwyczajna”, a ona sama jest narażona na wyzysk seksualny (Honeyman 2000, 17-34). Tam, gdzie mamy do czynienia z demografią służby, często tworzy się ją na podstawie wielkomiejskich źródeł sprzed około 1750 roku albo korzysta się z dziewiętnastowiecznych spisów ludności (Meldrum 2000; Higgs 1987, 59-80). Deborah Valenze zauważa, jak dużo z przekonań o osiemnastowiecznych służących jest uwikłanych w nasze wyobrażenia o tych z wieku dziewiętnastego. „Nowa służąca” epoki wiktoriańskiej (ta, której koleje losu rekonstruowaliśmy przez ostatnie sześćdziesiąt lat) „wydaje się udomowiona” - powiada Valenze - i pozbawiona „charakteru i sprytu [...]. Niezdolna do przygnębienia, jest lojalna i przyzwoita”; nie ma w niej głębi; nie może być niczym innym poza tym, kim jest (Valenze 1995, 167-168). To udomowienie domowej służby, które Valenze tak wyraziście opisała, było w dużej mierze efektem odebrania służbie domowej pewnych praw ustawowych, zwłaszcza prawa do meldunku na mocy ustawy o ubogich z 1834 roku. Osiemnastowieczne kobiety, które pisały zdumiewająco obraźliwe linijki o literackich i kulinarnych gustach swoich pracodawców albo kazały swojemu panu samemu ubrać własne dziecko, były osobami prawnymi $w$ takim sensie, $w$ jakim nie były już ich dziewiętnastowieczne następczynie. Ten fakt wyjaśnia do pewnego stopnia masową, uporczywą i natarczywą obecność służących we wszystkich formach kultury, jaką wytwarzali ich pracodawcy przez cały wiek osiemnasty (Steedman 2003, 316-350; Robbins 1993 [1986]). Ale to nie w tych rejonach społeczne historyczki i historycy czyhali na swoje historyczne podmioty.

Śladów tej kulturowo głośnej, ale demograficznie trudno uchwytnej osiemnastowiecznej służby na prowincji poszukuje się w orzeczeniach i spisach z epoki, jak czynią to historyczki robiące krok wstecz wobec perspektywy wieku dziewiętnastego (i jak zaraz, skrótowo, uczynię ja sama). Na przełomie dziewiętnastego i dwudziestego wieku co dwudziesta druga osoba z całej ludności Wielkiej Brytanii była służącą bądź służącym; w latach dziewięćdziesiątych dziewiętnastego wieku jedna trzecia zatrudnionych kobiet należała do służby domowej (Davidoff 1974, 406-428). Powołując się na badania z końca osiemnastego wieku, J. Jean Hecht i Bridget Hill dochodzą do wniosku, że jedna osoba na jedenaście była u kogoś na służbie, a w dużych miastach być może nawet jedna na sześć i, być może, między wczesną młodością a małżeństwem pracowało tak w osiemnastowiecznej 
Anglii czterdzieści procent całej ludności (Hecht 1956, 33-34; Hill 1996, 15-16; Laurence-Anderson 1981, 445). Większość tych danych wykorzystana zostaje w politycznej arytmetyce w Treatise of Indigence („Traktacie o nędzy”) Patricka Colquhouna z 1806 roku. Cytuje się z niego często, że w Anglii i Walii na 10 milionów całej ludności było 910 tysięcy służących, z czego 800 tysięcy kobiet. Ale w rzeczywistości Colquhoun wcale nie policzył, ani nawet nie oszacował liczby służących. Jego zamierzeniem w „Traktacie...” było wyliczenie dochodu narodowego odpowiednio do rangi i pozycji różnych osób i porównanie swoich wyników, powstałych na podstawie spisu ludności z 1801 i dokumentu Pauper Returns z 1806 roku, z tabelami i obliczeniami sporządzonymi przez Gregory’ego Kinga w roku 1688 (Colquhoun 1806, 23; Wrigley i Schofield 1989, 2-4, 571-572). Colquhoun napomyka o domowej służbie, żeby zamarkować jej nieobecność w klasyfikacji: interesowali go, ściśle rzecz biorąc, „pracownicy w majątkach ziemskich, manufakturach, handlu, żegludze i rybołówstwie itp. wyłączywszy służbę domową [podkreśl. - C.S.]”. W zasadniczej części jego rozprawy, traktującej o przyczynach ubóstwa, wspomina co prawda służących, ale tylko już odprawionych, czy to ze względu na nieumiejętność wykonywania pracy, choć nie zły charakter, czy to tych wydalonych za oszustwa, kradzieże i złe prowadzenie się. Służą oni za przykłady ilustrujące przyczyny nędzy, odpowiednio wróżące możliwość poprawy bądź zasługujące na potępienie (Colquhoun 1806, 11). Podczas gdy towarzystwa przyjaciół i banków oszczędnościowych dla pracującej biedoty prowadziły dyskusje, liczba zatrudnionych służących sięgnęła 110 tysięcy w przypadku mężczyzn i 800 tysięcy w przypadku kobiet - Colquhoun przyznaje, że ta ogromna liczba przedstawiać mogła „potencjalnych interesantów” owej ostoi ubogich. Jak pisze Leonard Schwartz, obliczenia Colquhouna zostały wykonane (lub wymyślone) w celu wzbudzenia paniki moralnej w kwestii luksusowych nawyków związanych z utrzymywaniem służby (Schwarz 1999, 236-256). Tak naprawdę zaś wśród ludności po prostu nie było dość młodych, niezamężnych kobiet, aby zapewnić taką liczebność służby domowej.

Przy szacowaniu liczby służących w Anglii od 1770 do 1820 roku ogromne znaczenie ma to, kogo tak naprawdę wliczamy, o czyja domową służbę chodzi, a także to, jak pracodawcy nazywali służbę. Kiedy w 1792 roku William Pitt zaproponował zlikwidować podatek od żeńskiej służby, powiedział, że w poprzednim roku podatkowym płaciło go 90 tysięcy „różnych rodzin [...] z raczej uboższych klas”, co daje sumę znacząco niższą niż ta o dekadę późniejsza z opracowania Colquhouna, nawet jeśli każde z tych gospodarstw utrzymywało świtę służących (The Parliamentary History of England 1814 t. 29, 829). Podatek od żeńskiej służby domowej okazał się wyjątkowo niepopularny i istniał jedynie przez siedem lat (w przeciwieństwie do podatku od męskich służących, który był w mocy od 1777 do 1937 roku). Był on krytykowany od swych początków w 1785 roku jako ciężar przede wszystkim dla rodzin z dziećmi, który spadnie zwłaszcza na biedniejszych i średnio zamożnych 
(to u nich bowiem samotna kobieta mogła znaleźć zatrudnienie przy domu i w gospodarstwie). Opłata taka miała nawet otwierać pewną drogę ku prostytucji, jak orzekło kilku członków parlamentu, bo kto miałby zatrudnić dziewczynę, jeśli miałby zapłacić 10 szylingów i 6 pensów podatku za jej służbę; a jeśli nie służbą, to czym innym mogłaby się ona zajmować? (The Parliamentary History of England 1785 t. 25, 246-267) Sprzeciwy te były tak uporczywe i skuteczne, że wysokość płac zaczęła ulegać ostrym wahaniom, a od prawa ustalono oszałamiająca liczbę wyjątków (The Parliamentary History of England 1785 t. 25, 596570, 812). Gospodarze jednak wcale nie ulegli oszołomieniu i bardzo szybko zorientowali się, że jeśli mieszkało z nimi dwoje lub więcej dzieci (lub wnuków), uzyskiwali oni zwolnienie z opłat za zatrudniane służące. I nawet w domach bezdzietnych, jeśli służąca była poniżej czternastego roku życia albo powyżej sześćdziesiątego, wtedy także podatku nie nakładano: „Odwołanie do Komisarzy dystryktu Hastings, hrabstwa Sussex... William Gilmore Croft of Battel niniejszym wnosi odwołanie od nałożonego nań podatku za jedną służącą i ponieważ posiada on dzieci poniżej 14 roku, jego odwołanie uznano i zwolniono [go] z opłaty" (Appeals before Commissioners 1785). Pitt zatem liczył gospodarstwa, które zatrudniały kobiety między 14 a 60 rokiem życia i w których nie mieszkały (legalne) dzieci poniżej 14 lat ${ }^{4}$. Jak zauważa Leonard Schwarz, służba domowa nie składała się też zawsze, a nawet w większości ze stałych mieszkanek i mieszkańców domu. Zwłaszcza kobiety mogły chodzić pracować do domów, gdzie przez krótko były wcześniej na stałej służbie; przez długi czas po ślubie i odchowaniu dzieci przychodziły ugotować dla towarzystwa obiad, wysprzątać pokoje, pomóc przy zmywaniu, za co płacono im od godziny lub dnia. Ustalając więc ilość płatnej domowej pracy wykonywanej przez kobiety, można założyć, że - bardziej niż twarde definicje wysnute na podstawie prawa podatkowego, na których pracował William Pitt bliższe prawdy mogą być nawet rozdmuchane sumy Colquhouna. Z pewnością możemy mówić o wszechobecności płatnej służby domowej, stanowiącej wówczas najczęściej spotykane doświadczenie zawodowe kobiet.

Często w odniesieniu do służących i domowej pracy, którą się kupuje, wydawało się sensowne siedzieć cicho. Praca w gospodarstwie wykonywana przez ludzi spoza rodziny często nie była pracą posłańców, pokojówek, kucharzy i lokai (to wszystkie kategorie służby wymienione $\mathrm{w}$ aktach parlamentu) zatrudnionych $\mathrm{w}$ konkretnym celu, na rok, z pensja wypłacaną wraz z jego końcem. Była to raczej praca wykonywana przez kobiety (i mężczyzn) kupowanych na godziny, pół dnia, trzy poranki, żeby wykonywać prace zlecone (umyć porcelanę w kredensie, poprasować, wyczyścić sprzęt do ważenia piwa, doprowadzić do porządku sypialnie) (Commissioners of Excise 1781, 139; Vickery 1998, 139). Wdowa

4 Ustawodawstwo uściślało, że dzieci, które zwalniają z podatku, muszą być legalne. Dający się wyczytać z podatku od służących i sposobów jego egzekwowania udział osiemnastowiecznego państwa w tym, co obecnie nazwano by polityką rodzinną, to temat na oddzielną rozprawę (Zob. Steedman 2009). 
z Somerstet, Frances Hamilton, która zarządzała odziedziczonymi kamieniołomem i pokaźną farma, była pracodawczynią dwóch kobiet służących, jednego służącego (który poza obsługiwaniem przy stole i odnoszeniem książek do biblioteki w Taunton robił bardzo dużo rzeczy w ogrodzie, kamieniołomie i polu) oraz kilku parafialnych praktykantów dziesięcioletnich chłopców, którzy pracowali na roli i w domu między rokiem 1778 a 1801. Ale w swoich rachunkach notowała ona też często (te zapiski pochodzą lat 1794 i 1799), że:

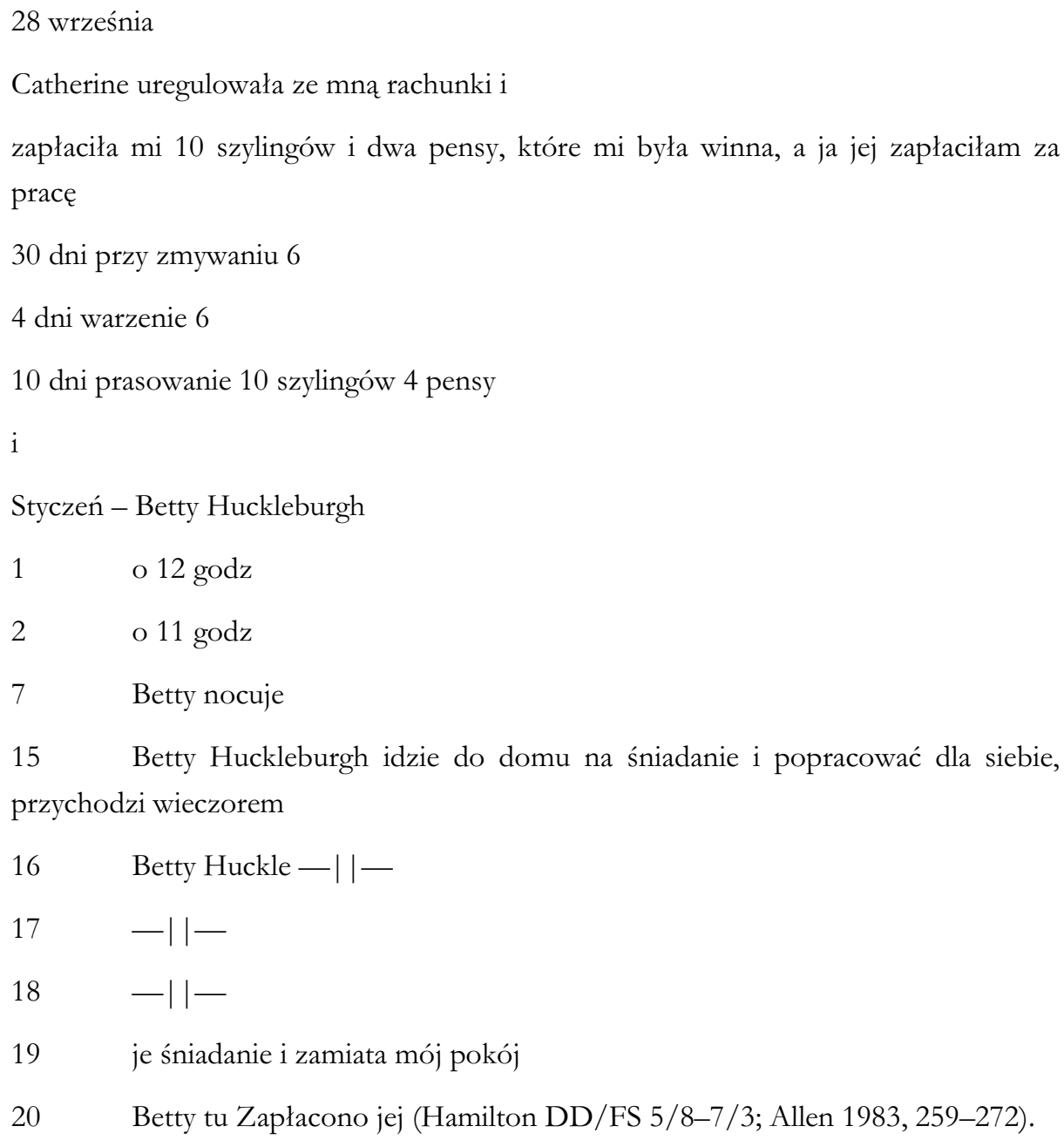

William Blackstone twierdził, że domownicy byli „w Anglii pierwszym rodzajem służących uznawanych przez prawo, nazywani tak od intra moenia" (mieszkający w murach domu, rezydenci) (Blaskstone 1775 [1765], 425). Prawo podatkowe i opodatkowanie pracy wykonywanej przez służbę przecinają na wskroś tę definicję prawną. Kiedy późnoosiemnastowieczni pracodawcy, urzędnicy [commissioners] i sędziowie mówili o „służących”, mieli na względzie wszystkie te definicje; możemy wyczytać, co mieli na myśli, rozpatrując kontekst używania przez nich tego terminu. Często, jak zobaczymy, po prostu opłacało się powiedzieć, że osoba służąca wcale nie była „służącą”. Potrzebujemy definicji, 
która uznaje zarówno ten niewielki odsetek ubranych w uniform i opodatkowanych lokai w peruce, usługujących w dużych domach, i liczbę tych, którzy przybywali i odchodzili ze wszystkich rodzajów skromniejszych domostw, takich jak Betty Huckleburgh (Huckleborough) i Catherine Vickery. Pojawiły się nowe rodzaje pracy polegającej na utrzymywaniu porządku w domu; w jego wnętrzu mnożą się nowe dobra - dywany, porcelana, zasłony, kuchenne utensylia - wymagające nowych rodzajów pracy, organizowanej zgodnie z nowym rytmem życia codziennego (Hill 1989, 103-147).

Późnoosiemnastowieczni komentatorzy, tacy jak Charles Fox wiedzieli, że najbardziej powszechnym doświadczeniem właścicieli gospodarstw nazywanych tu „biedniejszymi” było zatrudnienie młodej kobiety, która trzymałaby pieczę nad kuchnią oraz gospodarstwem, od których zależy codzienne życie ${ }^{5}$. Oprócz nowego prawa podatkowego były inne dobre powody nazwania jej „pomocnica na roli” (nawet jeśli gotowała obiady, ścierała kurze i prała pieluchy), ponieważ w przypadku, gdyby nie spełniła twoich oczekiwań, mogłeś wnieść skargę do magistratu, który zarządzany wedle starego ustawodawstwa, był zobowiązany wziąc pod uwage zdanie was obojga (Hill 1989, 69-102; Craven i Hay 2004, 59-116). Co więcej, prawo podatkowe zwalniało z opłat tych, którzy zatrudniali mężczyzn i kobiety przy prowadzonych przez siebie interesach (co obejmowało również handel produktami rolnymi) i dzięki pracy których ich pan albo pani zarabiali na życie albo bogacili się. Wielu pracodawców próbowało uzyskać takie zwolnienie, nazywając swoich lokajów i bojów wyrobnikami rolnymi (prawdopodobnie byli oni rolnikami od czasu do czasu, przekopujacc, przerzucając coś szuflą bądź widłami, taszcząc coś na wózku, itd., choć okazjonalnie podawali również do stołu, nosili wodę, sprzątali dom, pomagali w kuchni, czyścili noże i widelce, itp. To, czym się zajmowali, nie było odgraniczone kuchennymi drzwiami bardziej niż praca kobiet będących na służbie w domach wiejskich). Można było życzyć sobie, żeby magistrat sprawował pewną kontrolę nad twoją domową służąca (która nie doiła krów, nigdy nie pomagała przy żniwach, bywała nieposłuszna, odmawiała ubierania dziecka, podkradała, ukryła worek zboża w szopie, by ktoś z jej rodziny mógł go w nocy wynieść), i tę możliwość dawało nazywanie jej pomocnica na roli lub po prostu służąca (ale nie służbą domowa) ${ }^{6}$.

\footnotetext{
5 Terminowanie dziewczynek (i niewielkiej liczby chłopców) w gospodarstwach domowych rzuca światło na nieszczelną granicę oddzielająca prace w domu i poza nim. Zob. Snell 1985, 270-319. Więcej na temat terminowania kobiet, w tym terminowania w gospodarstwach domowych zob. Honeyman 2000, $26-27$. To właśnie praca służących płci żeńskiej zacierała różnicę między pracami wykonywanymi w domu i na zewnątrz (choć to niewłaściwy sposób ujmowania problemu, ponieważ dla osiemnastowiecznych pracodawców praca stanowiła niejako kontinuum). Zob. Hill 1989, 69-102; Parkyns 1724, 40. Więcej na temat nieszczelnej granicy między pracami wewnątrz domu i poza nim w Buckinghamshire w latach pięćdziesiątych osiemnastego wieku zob. Eland 1931 t. 1, 226-256.

6 „Ukradziono mi worek pszenicy i schowano w stajni pod sianem”, zanotowała 15 czerwca 1794 roku Frances Hamilton z Bishops Lydeard koło Taunton. Dwa tygodnie zajęło jej ustalenie, że zrobiła to Hannah Burston, która była z nią przez co najmniej siedem lat: „29 czerwca 1794 roku Hannah Burston zostaje wydalona. Miała ona zanieść worek pszenicy do spichlerzyka, znaleziono go jednak w stajni, gdzie postanowiła
} 
Wczesnodziewiętnastowieczni prawnicy myśleli, że w ciagu poprzedniego stulecia magistraty odpowiadały obydwu stronom, jakie składały się na instytucję służby domowej, egzekwowały władzę, której prawnie właściwie nie posiadały, zakładały bowiem, że wszystkie kobiety, które przyszły do sądów, były rzeczywiście pomocnicami na roli. Wiedzieli oni dobrze, że prawodawstwo odnosiło się - wedle słów Jamesa Barry’ego Birda z 1799 roku „zwłaszcza do rzemieślników oraz pomocnic i pomocników na roli, ale imaginuje się, że można je wykładać tak, by uzasadnić ogólną jurysdykcję obejmującą służbę podpadająca pod każdy opis i taka jurysdykcja rzeczywiście ja obejmowała” (Bird 1799, 3). W roku 1812 Thomas Waller Williams sądził, że w poprzednim wieku (jest to ładny przykład tego, co nazywa się fikcja prawna) magistraty po prostu zakładały, iż wszyscy służący byli „służącymi na roli”, a zatem osobami podległymi jurysdykcji (Waller Williams 1812 t. III, 887-893; Burn 1793 t. II, 325-328; Ruggles 1793 t. II, 255).

Dane Colquhouna z 1806 roku o 800 tysiącach służących płci żeńskiej, pewniejsze dane Pitta z roku 1791 o 90 tysiącach gospodarstw płacących podatek pokazują co najmniej powszedniość doświadczenia służby dla obu jego stron. Dużo uwagi poświęcono pracom Sary Mazy i Cissie Fairchild na temat służby we Francji i ich z uporem powtarzanej tezie, że służba była doświadczana przede wszystkim jako relacja (Maza 1983; Fairchilds 1984). Ich badania pomijają przy tym klasowy aspekt tej relacji i ograniczają się do wymiaru emocjonalnego oraz afektywnego. Badanie takie - jak na przykład osadzona w latach osiemdziesiątych osiemnastego wieku, zwięzła, ale błyskotliwa opowieść Amandy Vickery o Elizabeth Schackleton i o tym, jak postrzegała ona swoją żeńską służbę - zawsze opatrzone jest znajomym, cokolwiek pełnym rezygnacji zastrzeżeniem historyczki społecznej, że nigdy nie dowiemy się, jak przez służbę była postrzegana Elizabeth Shackleton (Vickery 1998, 134 $146)^{7}$.

Ujęcie Vickery, skoncentrowanej na służbie z prowincjonalnych okolic, jest ujęciem wyjątkowym; twórcy większości ostatnich prac korzystali ze źródeł wielkomiejskich, by odnajdywać służące i służących zatrudnianych przez stosunkowo niższe warstwy ludności rzemieślniczej Londynu epoki augustiańskiej (Earle 1989, 218-230), a przede wszystkim, by odnajdywać kobiety i kobiece doświadczenie. Służba domowa tych kobiet często postrzegana była przez historyczki jako efekt ich wyboru, jako sposób na uniknięcie małżeństwa i zachowanie niezależności (Kent 1989, 111-128; Meldrum 2000). Z perspektywy dużego miasta angielskie historyczki społeczne nie mogą być już dłużej oskarżane, jak w roku 1976, o ignorowanie służących, dlatego że były one kobietami (McBride 1976, 9-17). Zarazem powiększyła się nasza wiedza o terminowaniu, a zwłaszcza o tym, jak na różne

go ukryć i zataić przede mną ten postępek”. Hamilton nie angażowała w sprawę lokalnego magistratu (Hamilton, DD/FS 5/2).

${ }^{7} \mathrm{Na}$ temat relacji służby jako relacji klasowej zob. Steedman 2009. 
sposoby powoływano się na nie, by zapewnić gospodarstwom służbę domowa płci żeńskiej (a czasami także męskiej), zwłaszcza na prowincji (Snell 1985, 257; Hill 1989, 85-102; Keeling 1914; Lane 1996). W grudniu 1810 roku w Leeds na jednym z sądowych posiedzeń w sprawie odwołań podatkowych członkowie komisji wysłuchali apelacji panów A. i R. Leigh, handlarzy tkanin kwestionujących domiar podatkowy od „młodego człowieka, którego wzięli w termin, żeby uczyć go handlu [...], od czego magistraty nie odciagaja podatku. Rzeczony uczeń wykonuje wprawdzie prace typowe dla lokajów w liberiach, gdyż regularnie podaje do stołu etc., ale jego panowie wcale nie kazali mu nosić liberii... gdyż uważają go za sługę co najwyżej od okazji”. Członkowie komisji i sędziowie sądu najwyższego zdecydowali jednak inaczej i nałożyli na Leighów podatek (Assessed Taxes 1805-1830). Kilka lat wcześniej rządowi komisarze, zbierając zeznania odnośnie do prawnej regulacji handlu wełna, zapytali producenta i kupca tekstylnego z Huddersfield, czy „lokalni służący mogli być, w swych młodych latach, zatrudniani przy handlu tkanin?”. Ten zaprzeczył i powiedział, że „,mogli oni pracować przy krosnach, ale na pewno nie przy tkaninach”. Nie wspominamy tu już o nieoficjalnym porozumieniu, które pracodawcy mogli zawierać ze wszystkimi, których zatrudniali bądź uczyli, niezależnie od płci, zobowiązującym ich do utrzymywania domowego porządku (Minutes of Evidence 1803, 871-881).

John Murgatroyd płacił podatek od Phoebe Beatson - w świetle prawa podatkowego jego gospodarstwo należało do typowych. Odnotował on, że lokalny asesor zapukał do jego drzwi ze spisem w ręku, na co on sam wysłał Phoebe, by zapłaciła podatek za siebie oraz uregulowała resztę opłat. Nie było raczej podstaw, żeby się odwoływać: żadnych dzieci, jedna służąca płci żeńskiej, a zatem żadnych zwolnień. Był to prawdopodobnie najbardziej typowy układ, w którym domowe służące żyły i pracowały: gospodarstwo z jedną służąca. Podajmy przykład jednej z miejscowości, gdzie przetrwały podatkowe rejestry opłat od kobiet służących: w Shrewsbury w kwietniu 1786 roku właściciele gospodarstw zapłacili podatki od 176 służących płci żeńskiej, z których 83 (47 procent) zostały scharakteryzowane jako pojedyncze służące. (Obejmowało to również kobiety wykonujące prace w różnych domach, ale w deklaracjach podatkowych Shrewsbury nazywane „mieszkankami” domu kogoś innego, figurującego jako właściciel gospodarstwa na potrzeby urzędu podatkowego). Pozostałe 25 kobiet (14 procent) pracowało wraz z innym służącym (częściej służąca). W tej stolicy hrabstwa 30 opodatkowanych służących płci żeńskiej (17 procent) pracowało w dużych domostwach zatrudniających 6 lub więcej służących (znów, zarówno płci męskiej, jak i żeńskiej) (An Assessment of the Township 1786). Niektóre z tych gospodarstw deklarujących tylko jedną służąca mogły być zwolnione z podatku z drugiej służącej płci żeńskiej ze względu na obecność dzieci; niektóre, poza wykazywaną zatrudnioną, mogły zatrudniać młodą dziewczynę lub starszą kobietę. Ta ogólna suma z pewnością zaniża więc liczbę służących zatrudnionych w danej miejscowości. Ale liczby te pozwalają nam powiedzieć 
z jaką̧ś doza pewności, że to gospodarstwa z jedną osobą na służbie były najczęstszym układem w końcu osiemnastego wieku. W Doncaster w okresie podatkowym kończącym się w kwietniu 1789 roku 167 pracodawców płaciło podatek od 241 służących płci żeńskiej: 129 (60 procent) z nich pracowało w pojedynkę, 40 (18 procent) w gospodarstwach $z$ dwiema służącymi ${ }^{8}$. Żadne kalkulacje natomiast nie uwzględniają ogromnej rzeszy pomocnic, osób zatrudnianych w niepełnym wymiarze godzin, pracownic wynajmowanych do konkretnych prac; ani w Shrewsbury, ani w Doncaster; ani w biurze podatkowym, ani w Slaithwaite.

Domowa służba nie jest już nieobecna w historiach kobiet i kobiecej pracy, ale wciąż, niezależnie od płci służby, nie znajdziemy poważniejszych świadectw jej obecności w politycznych i społecznych historiach Wielkiej Brytanii, w okresie przejścia do kapitalistycznej nowoczesności. Tymczasem wszelkiego rodzaju służba domowa była zawodem najczęściej wykonywanym przez kobiety. Ogromna liczba kobiet z klasy pracującej pracowała w którymś momencie swojego życia jako służąca, wiele z nich żyło w bezpośredniej bliskości ze swoimi przełożonymi. Ale w historiografii stosunków klasowych, od The Making of the English Working Class Thompsona (1963) do The Struggle for the Breeches Anny Clark (1995), nie uznaje się znaczenia służby z punktu widzenia klasy. Teza, jaką sformułował w kwestii kształtowania się stosunków klasowych Thompson, była już dogłębnie analizowana, „,naginana”, zniekształcana, przesuwana w czasie do przodu i do tyłu, a także „upłciawiana”; służące jednak nie stały się przez to w większym stopniu częścią tej opowieści od czasu, gdy pisano ja po raz pierwszy (Morris 1979; Neale 1981; Rule 1981; Wallach Scott 1988, 68-90; Sewell 1990, 50-77; Hall 1990, 78-102; Joyce 1995; Wood 1999). W przypadku historii społecznej i historii pracy wymazanie tej masowej obecności służących nie jest efektem trudności z ich wytropieniem, oszacowaniem skali zjawiska ani nawet z podaniem ich nazwisk. Służących tam nie ma raczej z tego względu - jak pokażę w rozdziale trzecim - że nie ma ich jeszcze w opowieści, którą tworzą (lub powtarzaja czy przekształcaja) historyczki społeczne; nie ma ich tam odkąd w latach siedemdziesiątych osiemnastego wieku Adam Smith jako pierwszy nazwał ich pracę „nie-praca”, i dlatego że Karol Marks sięgnął po jego teorię ponad sto lat później, a dwudziestowieczne historyczki społeczne wykorzystały obydwa dzieła, pisząc historię angielskiej klasy robotniczej. Phoebe Beatson pozostaje niema nie tylko dlatego, że nie umiała pisać, że John Murgatroyd nigdy nie zanotował jej słów w swoim dzienniku, że akta z jej wizyty w magistracie w 1802 roku nie zachowały się, ale również dlatego, że opowieści mające na celu odzyskać jej obecność i zrekonstruować jej doświadczenie są oparte na schemacie fabularnym, który nie uwzględnia kobiet (i mężczyzn) takich jak ona. Włączenie Phoebe Beatson (i relacji między nią a Johnem

8 W mieście było jedno duże domostwo, w którym na siedmioosobową służbę przypadały trzy (opodatkowane) kobiety - był to jeden procent wszystkich służących płci żeńskiej. Siedem gospodarstw płaciło za trzy pokojówki. Tylko jedno w całym mieście płaciło za cztery (Doncaster Window Duty 1789). 
Murgatroydem) w proces powstawania angielskiej klasy robotniczej nie obali tezy Thompsona, lecz wpłynie na nią na poziomie strukturalnym. Książka ta jest po części próbą przekonania się, co stanie się z pewną historiografią, gdy większość klasy robotniczej dołączy do własnej historii.

Milczenie, z jakim John Murgatroyd przyjmuje wydarzenia z lat 1801-1802, gdy Phoebe Beatson poczęła i urodziła swoje nieślubne dziecko (albo - w szerszej perspektywie milczenie, w jakim upływają mu lata 1786-1806 czy 1739-1806), jest innego rodzaju. Jakaś jego część wynika pewnie z braku dokumentów. Z lat 1783-1785, 1787, 1792-1793, 1795, 1799 i 1803 nie zachowały się żadne dzienniki. Canon Hulbert, wiktoriański historyk Murgatroyda, na okładce pierwszego z ocalałych dzienników z roku 1782 zanotował: „poprzednich brak”. Braku dzienników nie można tłumaczyć bezpośrednią reakcja na wybuch wojen z Francją w 1792 roku, ani relacjami o klęsce urodzaju i głodzie. O Aktach Poborowych z 1795 roku i żądaniach postawionych hrabstwu Yorkshire, by dostarczyło do armii 609 mężczyzn, Murgatroyd nie wspomina również w następnym roku, z którego zapiski akurat ocalały. W roku 1798 musi milczeć na temat dymisji Wiceprzedstawiciela Korony w West Riding (książę Norfolk wiwatował na cześć Charlesa Jamesa Foxa, jakby był on kimś w rodzaju George’a Washingtona, chcąc ofiarować swojemu krajowi taką wolność, jaką cieszą się Amerykanie) (Emsley 1979, 67). Nie pojawia się też później dyskusja o pokoju zawartym w Amiens (1802) czy zaciagu milicji i mobilizacji regularnej armii przed wypowiedzeniem wojny w maju 1803 roku, mimo że część okresu rozejmu z Amiens, przypadającego zresztą na czas ciąży i połogu Phoebe Beatson, mieści się w jego notesach (Emsley 1979, 38-42, 49, 53, 99-123). Prawdopodobnie jednak o lokalnych reperkusjach wojny oraz jej ekonomicznym i politycznym wpływie na West Riding Murgatroyd napisal dużo więcej niż to, co po nim zostało; w ocalałych dziennikach bowiem szczegółowo zdaje sprawę z wpływu, jaki wojna wywarła na handel wełną, obserwowanego zreszta przez pryzmat pracy Phoebe jako prządki i niewypłacalności jej pracodawcy ${ }^{9}$. Regularnie czyta on prasę z Manchesteru i Leeds, pożycza gazety od gości i regularnie zachodzi po wieści do Slaithwaite. Ma wyrobione zdanie na temat pewnych wydarzeń narodowych i zna ich wagę, tak lokalną, jak i boska. Drugiego stycznia 1794 roku pisze, że „parlament musi dziś, na rany Chrystusa, swoje serca do dyspozycji oddać miłości, jedności i pokojowi”; wie też, co do godziny, kiedy wyższa izba brytyjskiego rządu obradować miała nad uznaniem Republiki Francuskiej (Murgatroyd 1794) ${ }^{10}$. Wypowiadając się przeciw ciąłej wojnie z perspektywy znanej w handlowych i kupieckich centrach branży wełnianej i tekstylnej, hrabia Guildford miał ostrzegać: ,jeśli osuszysz francuskie źródła twoich dóbr, do upadku

\footnotetext{
${ }^{9}$ Zob. rozdział 4.

10 O przemówieniu króla na otwarcie sesji zob. Parliamentary History of England 1792-1794, 1045-1048; o interesującej Murgatroyda - debacie lordów na ten temat zob. Parliamentary History of England 1792-1794, 1062-1088.
} 
doprowadzisz własne rynki. Jeśli zniszczysz Francję, pozbawisz ją towarów na wymianę i pieniędzy na zakup tego, co masz na sprzedaż”. Wiceprzedstawiciel Korony w West Riding (jeszcze niezwolniony ze stanowiska) popierał ten pogląd. Hrabia Derby „czuł odrazę do wszystkich okrucieństw popełnionych przez Francuzów”, ale uważał, że „umiłowanie pokoju powinno wziąć górę nad innymi względami”. Ci jednak byli w mniejszości: wszyscy duchowi przywódcy, a także większość świeckich obrócili swoje serca przeciw pokojowi, handlowemu czy boskiemu. Tego rodzaju politycznych komentarzy - wygłaszanych z perspektywy Chrystusowego sługi - mogło być w innych dziennikach Murgatroyda więcej, i więcej mogło być politycznych spostrzeżeń, jak to z czerwca 1796 roku, kiedy zanotował, że „zajęci są zabieganiem o poparcie Twego Królestwa dla Nowego Parlamentu” (Murgatroyd 1796). Swoje pozostałe notatniki zapełniał zapiskami w tym samym duchu, obserwując bieżące wydarzenia, choć jego wpisy są tu niedatowane: niepokój związany z powszechną mobilizacją i obroną kraju został prawdopodobnie odnotowany w roku 1802, choć nie znajdziemy go w dziennikach, które się zachowały ${ }^{11}$.

Wojenny budżet Pitta i napinanie skarbowych muskułów zmilitaryzowanego państwa mogły zostać opisane przez Murgatroyda w dzienniku pozostałym z roku 1794, w którym to wprowadzono podatki od adwokatów, alkoholi wysokoprocentowych, cegieł i dachówek, szkła walcowanego i papieru (Emsley 1979, 49; O’Brien 1989, 165-187; Beckett 1985, 285308; Beckett i Turner 1990, 377-403). Budowa nowego domu, w którym Murgatroyd mial zamieszkać po przejściu na nauczycielską emeryturę, została co prawda ukończona w 1790 roku, potem jednak zatrudni on radcę prawnego z Huddersfield, będzie pił nie mniej niż wszyscy inni i kupował spore ilości papieru - w swoim dzienniku nie odnotowuje mimo to wzrostu kosztów życia. W 1795 roku wprowadzono kolejne podatki - od wina, herbaty i pewnych gatunków drewna z importu, od ubezpieczenia na życie, pudru do włosów (produkowanego z kosztownej mąki pszennej). W 1796 istniejące już podatki (od okien, koni i męskich służących) zostały podniesione o dziesięć procent; pojawił się nowy podatek od tytoniu; podatek od koni rekreacyjnych podwoił się i wprowadzono nowy podatek od koni pociagowych. Podatek od perkaliku wzrósł niemal dwukrotnie, do sześciu pensów za jard. W 1797 roku podrożały herbata, alkohol, cukier i budowa domów. Patrick O’Brian wylicza, że podczas dwudziestu dwóch lat wojny z Francja (z których Murgatroyd przeżył czternaście), od 1793 do 1815 roku „około 63 procent dodatkowych - potrzebnych na wojnę wpływów do skarbu państwa [...] brało się z podatków odciaganych [...] od dochodów i konsumpcji bogatych”. I rzeczywiście, na ile da się to rozróżnić, taka właśnie była polityka [policy] kolejnych rządów (O’Brien 1988, 1-32; Ward 1953). Jednak coraz więcej nowych i podwyższonych podatków nakładano również na towary i usługi, z których korzystały

11 Zob. rozdział 2. 
średnio zamożne gospodarstwa; przez ostatnich dziesięć lat życia Murgatroyda koszt utrzymania domu równomiernie wzrastał. A przecież nie miał on konia ani męskiego służącego, który by potrzebował pudru do włosów (choć mógł go kupować do własnej peruki, którą nosił uparcie do dnia swojej śmierci); palił swój własny tytoń i popijał alkohole kupowane w Rochdale. Płacił podatek od służącej Phoebe Beatson w trakcie krótkiego okresu obowiązywania tego nadzwyczaj niepopularnego rozwiązania, zniesionego w roku 1792. Jeśli cokolwiek wniósł do „Zbiórki Lojalnościowej”, ogłoszonej w grudniu 1796 roku z zamiarem zebrania 18 milionów funtów na działania wojenne, to nie odnotował tego w swoim dzienniku. W jego archiwum nie ostały się żadne księgi rachunkowe (tak samo jak nie ostały się rejestry deklaracji podatkowych West Riding). Księgi rachunkowe mogłyby pewnie zrekompensować przemilczenia Johna Murgatroyda w kwestiach handlowych i politycznych; jednak to, z czym zostajemy, to pisma człowieka, który prowadził swój dziennik, by odnotowywać codzienne drobiazgi (stan budowy nowego domu i utarczki z budowlańcami, towarzystwo przy obiedzie i zbiory z warzywnego ogródka, praca przy przędzy swojej służącej i nowy przepis na przyrządzanie mięsa nie pierwszej świeżości) oraz opisywać swoja relację z Bogiem. Warto też zauważyć, jak szeroka jest historyczna perspektywa, do której odnosi on bieżące zdarzenia i na tle jakiego rodzaju publicznej historii widzi on swoje życie; w roku 1802 zapisuje: „Król Jerzy III wkracza dziś w 65 rok swego życia, a ja w 65 rok mojej służby publicznej”. Jako pastor anglikańskiego Kościoła początek swej politycznej epoki umiejscawia w siedemnastym wieku; odtąd trwa ona w permanentnym czasie teraźniejszym: „Wszystko miłościwie zachowane”, notuje tego roku w rocznicę stracenia króla. „Przyjemny dzień. Ścięcie króla Karola, bardzo ciężki czas dla Anglii” (Murgatroyd 1802).

Milczenie Murgatroyda zatem nie wymaga dopowiedzeń. W tej książce chcę zrekompensować milczenie Phoebe Beatson, na ile mogę to zrobić, opowiadając o niej jako o typowej służącej. Na końcu, w dużo odważniejszym geście, odczytuję Wichrowe Wagórza (1847), powieść, w której akcja ulokowana jest na pastwiskach West Yorkshire między 1770 a 1800 rokiem, jako powieść historyczna, którą faktycznie jest. Tę opowieść (czy raczej historię, jak próbuję dowieść) snuje jedna ze wspanialszych służących-narratorek w nowoczesnej literaturze - Ellen (Nelly) Dean. Tutaj bez watepienia służąca ma głos; ogromne połacie tekstu przemawiają (wymyślonym) głosem przedstawicielki pennińskiej klasy pracującej. Zależy mi na tym, żeby zobaczyć, co można wydobyć ze spostrzeżeń i sposobu myślenia dziewiętnastowiecznej powieściopisarki, która zdecydowała się odtworzyć głos służącej - kogoś, kto stoi niżej na drabinie społecznej oraz na przekonaniu się, co Emily Brontë wiedziała lub wierzyła, że wie, o służbie domowej w niedawnej historycznej przeszłości wieku osiemnastego. Opowieść (lub historia) Brontë swój początek miała również w domu pastora, tak jak ta, którą zaraz przedstawię. 
Znaczenie, mit i fikcja sa jednak w centrum zainteresowania tej książki od samego początku, na długo zanim dochodzimy w niej do Wichrowych Wagór: Najważniejszym opracowaniem dotyczacym West Riding tego okresu pozostaje The Making of the English Working Class Edwarda Thompsona, dla którego archiwa Yorkshire, zawierające annały pracującej biedoty, stanowiły bardzo ważne źródła. Moja książka to początkowa próba wprowadzenia domowej służby do tego dramatu o formowaniu się klasy. I rzeczywiście jest a nie był - to dramat: w większości mamy tu bowiem do czynienia z dominującymi interpretacjami dwudziestowiecznych historyków, a nie ze świadectwami samych historycznych podmiotów. Interpretacje te z kolei urosły do rangi mitów o formowaniu się klasy i narodu. Historie takie jak Thompsona oraz te wzorowane na niej pozostaja ważnymi socjohistorycznymi opracowaniami, ale w szerszych społecznych zastosowaniach obecne w nich argumenty zaczynaja pełnić funkcje mitologiczne, ponieważ tłumaczą one początki panującego porządku społecznego: to, jak rzeczy zaczęły być tym, czym są ${ }^{12}$. Dlatego tak pouczająca okazuje się lektura Wichronych Wagórz równolegle z The Making of English Working Class - obydwie te książki stały się mitami społecznych początków, wywodzącymi się z i dotyczącymi tego samego geograficznego regionu oraz tego samego historycznego okresu. Faktycznie jednak, w przeciwieństwie do historycznego mitu z książki Thompsona, Wichrowych Wagórz czytelnicy nie musieli przerabiać na mit; od momentu, w którym Ellen Dean otwiera usta, opowiada ona „pewien mit początku” (Gilbert i Gubar 2000, 292). To, co nastąpi tutaj, można więc przeczytać jako zastąpienie jednego mitu (lub zestawu mitów) innym. Ten nowy mit to mit o Phoebe z West Riding - jej opowieść mieści w sobie wydarzenia i perspektywy odmienne od tych, które są nam na ogół przekazywane. Mówiąc bardziej prozaicznie, książka ta opisuje splatające się historie osobiste trojga ludzi, opowiada o tym, jak doświadczali oni życia, miłości oraz pracy w miejscu klasycznym dla klasowego formowania się Anglii. Może ona służyć do zmodyfikowania i skomplikowania opowieści o początkach angielskiej, kapitalistycznej nowoczesności, którą już dysponujemy. Jeśli relacja między Johnem Murgatroydem i Phoebe Beatson zawiązałby się gdzie indziej, nie w West Riding, miałaby ona mniejsze znaczenie dla prób przepisania historii angielskiej klasy robotniczej. Jako że zawiązała się ona jednak tu, ta opowieść o służącej i jej panu, oraz o życiu, które przeżyli razem, rzuca nowe światło na ten sam materiał, z którego Thompson zbudował swoją narrację, rozgrywającą się w dużej mierze wśród tych samych pastwisk West Yorkshire. W ten sposób prosi się tu czytelniczki i czytelników, by zastanowili się, jakiego rodzaju opowieścia jest ta „historia” i jakie efekty wywoływać moga takie opowieści, oraz by dostrzegli ich stały potencjał do zmiany, kiedy na światło dzienne wychodzą nowe dowody.

\footnotetext{
12 Więcej na temat przemieszczeń między oficjalną historią akademicką a jej użyciem w powszechnej i politycznej wyobraźni (włączając wyobraźnię historyków) zob. Eley 2005, 152-155.
} 
Istnieje wiele badań na temat West Riding w Yorkshire: ziemia między Aire i Calder (czyli całe West Yorkshire) - jak zobaczymy - nawiedzana będzie przez historyczki i historyków (wiele i wielu z nich to historycy osiemnastego i dziewiętnastego wieku), którzy napisali jego demografię, wyjaśnili jego industrializację, ustanowili związek między dobrobytem wiejskiej produkcji i małżeńskimi zwyczajami, i znaleźli niemało jego nieślubnych dzieci, by móc potem badanej ludności wystawić cenzurkę z zachowania. Pod koniec istotnego i pouczającego studium dwóch miasteczek na północ od Slaithwaite Calverly i Sowerby - Pat Hudson i Steve King kwestionują stosowane przez demografów historycznych i historyków ekonomicznych metody (które sami skądinąd rozwijali) polegające na wyznaczaniu związków między ludzkim zachowaniem a „ogólnym ekonomicznym klimatem [...], przesunięciami realnych płac, czynnikami, od których płaca zależy [...] i dominującymi zawodami [...]" (Hudson i King 2000, 706-741). Jak wskazują, w przypadku grup podporządkowanych (a Phoebe Beatson i George'a Thorpa musimy zaliczyć do takiej grupy) zrozumienie związków między zachowaniem a powyższymi czynnikami graniczy z niemożliwością; częściowo dlatego, że nie istnieją żadne dokumenty, które pozwoliłyby rozrysować taki wykres (Hudson i King musieli dokonać cudów z nędznymi protokołami sądowymi), ale przede wszystkim (czego nie mówią oni wprost) dlatego, że nie musi wcale zachodzić żaden związek między ekonomicznymi siłami, rozróżnialnymi dla oka współczesnego historyka, a chwilą (namiętności? zapomnienia? decyzji? przekonania?), kiedy poczęte zostaje dziecko, które prawo, państwo i przyszli historycy społeczni postanowia nazwać bękartem. Dzięki tym komentarzom pojawia się myśl - przyprawiająca o zawrót głowy i niepokój - że przedsięwzięcie historii gospodarczej i społecznej służyło tyleż odsłonięciu, ile zakryciu egzystencji takich osób jak Phoebe Beatson. Proponowane przez nich rozwiązanie szokuje i intryguje jednocześnie: chodziłoby o to, by przestać polegać na wyuczonych historiach dotyczących tendencji ekonomicznych w celu wyjaśnienia zachowań dawnego proletariatu i spróbować pomyśleć, że to zachowania i ludzkie relacje same maja moc kształtowania życia. Owe zachowania i relacje będą zakorzenione w tym, co lokalne i wernakularne - przywiodą na myśl wzgórza, którymi się przechadzasz, wełnę, którą obrabiasz, Boga, w którego wierzysz. Dopiero wtedy twoja historyczka będzie w stanie dostrzec ciebie, już nie jako ciche potwierdzenie demograficznej tendencji (jak wzrost urodzeń nieślubnych dzieci w odniesieniu do deklarowanego ogólnego dobrostanu w relacjach małżeńskich lub jak związek między protoindustrializacją i wzrostem populacji) i już nie jako bierne odzwierciedlenie przesunięć w realnych płacach dla robotnic przemysłu tekstylnego, ale jako aktorkę swego własnego życia. By to zrobiła, twoja historyczka będzie potrzebowała bardzo szerokiej definicji kultury materialnej, obejmującej wszystkie przedmioty wytworzone przez kobiety i mężczyzn (które ze swej strony wytwarzają ich): a w tym i miłość, i pracę, zarówno wiarę, jak i rodzenie nieślubnych dzieci. 


\section{Wykaz literatury}

Allen, Margaret. 1983. "Frances Hamilton of Bishops Lydeard." Notes and Queries for Somerset and Dorset 31: Part 317.

An Assessment of the Township ... for the Taxes on Male, Female Servants, Coaching Horses, Waggons, Carts. April 1786. Shrewsbury: Shropshire Records and Research. 3365/374.

Appeals before Commissioners. 1770-1785. Appeals heard determined at Meeting of the Commissioners beld at the George Inn Battel the 21st day of January 1785. Hastings: Sussex. PRO, IR 83/131.

Assessed Taxes and Inhabited Houses Duties. Judges Opinions. 1805-1830. Vol. III. February 1810June 1830. PRO, IR 70/3.

Beckett, John V. 1985. "Land Tax or Excise. The Levying of Taxation in Seventeenth- and Eighteenth-century England.” English Historical Review 100.

Beckett, John V. i Michael Turner. 1990. "Taxation and Economic Growth in Eighteenthcentury England.” Economic History Review 43:3.

Blackstone, William. 1775. Commentaries on the Laws of England. In Four Books. orig. pub. 1765. 6th edn. Dublin: Company of Booksellers.

Clifton JP, Sir Gervase. 1785. 1772-1812, M8050, Notebook [b. d.; prawdopodobnie listopad 1785]. Nottingham: Nottinghamshire Record Office.

Colquhoun, Patrick. 1806. A Treatise on Indigence; Exbibiting a General View of the National Resource for Productive Labour. London: J. Hatchard.

Commissioners of Excise. 1781. Abstract of Cases and Decisions on Appeals Relating to the Tax on Servants. London: Mount and Page for T. Longman and T. Cadell.

Craven, Paul i Douglas Hay. 2004. Masters, Servants and Magistrates in Britain and the Empire, 1562-1955. Chapel Hill and London: University of North Carolina Press.

Davidoff, Lee. 1974. "Mastered for Life: Servant and Wife in Victorian and Edwardian England." Journal of Social History 7:4.

Doncaster Window Duty. 1789. Doncaster: Metropolitan Borough Council Archives. AB6/2/17.

Earle, Peter. 1989. The Making of the English Middle Class. Business, Society and Family Life in London, 1660-1730. London: Methuen.

Eland, G. [Red]. 1931. The Purefoy Letters 1735-1753, 2 vols. London: Sidgwick and Jackson.

Eley, Geoff. 2005. A Crooked Line. From Cultural History to the History of Society. Ann Arbor: University of Michigan Press.

Emsley, Clive 1979. British Society and the French Wars, 1793-1815. Basingstoke: Macmillan.

Gilbert, Susan M. i Susan Gubar. 2000. The Madwoman in the Attic. The Woman Writer and the Nineteenth-century Literary Imagination. New Haven: Yale University Press.

Hall, Catherine. 1990. "The Tale of Samuel and Jemima. Gender and Working Class Culture in Nineteenth-century England." W E.P. Thompson. Critical Perspectives. Red. Harvey J. Kaye i Keith McClelland. Cambridge: Polity Press.

Hamilton, Frances. 1794. Bishops Lydeard Farming Accounts. Taunton: Somerset Country Record Office (28 September 1794, 20 January 1799). DD/FS 5/8-7/3. 
Hecht, J. Jean. 1956. The Domestic Servant Class in Eighteenth Century England. London: Routledge and Kegan Paul.

Higgs, Edward. 1987. "Women, Occupations and Work in the Nineteenthcentury Censuses." History Workshop Journal 23.

Hill, Bridget. 1989. Women, Work and Sexual Politics in Eighteenth-century England. Oxford: Blackwell.

Hill, Bridget. 1996. Servants. English Domestics in the Eighteenth Century. Oxford: Clarendon Press. Honeyman, Katrina. 2000. Women, Gender and Industrialisation. Basingstoke: Macmillan.

Hudson, Pat i Steve King. 2000. “Two Textile Townships, c. 1660-1820. A Comparative Demographic Analysis.” Economic History Review 53:4.

Joyce, Patrick. [Red.] 1995. Class. Oxford: Oxford University Press.

Keeling, Frederic. 1914. Child Labour in the United Kingdom. London: P. S. King.

Kent, D.A. 1989. "Ubiquitous but Invisible. Female Domestic Servants in Mid-Eighteenthcentury London.” History Workshop Journal 28.

Landry, Donna. 1990. The Muses of Resistance. Labouring-Class Women's Poetry in Britain, 1739_ 1796. Cambridge: Cambridge University Press.

Lane, Joan. 1996. Apprenticeship in England, 1600-1914. London: UCL Press.

Laurence-Anderson, Judith. 1981. "Changing Affective Life in Eighteenth Century England and Samuel Richardson's Pamela." Studies in Eighteenth Century Culture 10.

McBride, Theresa. 1976. The Domestic Revolution. The Modernization of Household Service in England and France, 1820-1920. London: Croom Helm.

Meldrum, Tim. 2000. Domestic Service and Gender, 1660-1750. Life and Work in the London Housebold. London: Longman.

Minutes of Evidence taken before the Commissioners, to whom the Bill, respecting the Laws relating to the Woollen Trade, is committed, Parliamentary Papers. 1803 III (Part 3).

Morris, Robert J. 1979. Class and Class Consciousness in the Industrial Revolution, 1789-1850. London: Macmillan.

Neale, R.S. 1981. Class in English History, 1680-1850. Oxford: Basil Blackwell.

O’Brien, Patrick K. 1988. “The Political Economy of British Taxation, 1660-1815.” Economic History Review 41.

O’Brien, Patrick K. 1989. "Public Finance and the Wars with France, 1793-1815.” W Britain and the French Revolution, 1789-1815. Red. Harry Thomas Dickinson. Basingstoke: Macmillan.

Parkyns, Thomas. 1724. A Method Proposed, for the Recording of Servants in Husbandry, Arts, Mysteries, Eetc. Offer'd by Sir Thomas Parkyns, Bart., One of His Majesty's Justices of the Peace for the Counties of Nottingham and Leicester. London: Privately printed.

Murgatroyd, Reverend John. 1794. Diaries. Kirklees District, Huddersfield: West Yorkshire Archive Service. KC242/2.

Robbins, Bruce. 1993. The Servant's Hand. English Fiction from Below. orig. pub. 1986. Durham and London: Duke University Press

Rule, John. 1981. The Experience of Labour in Eighteenth-century Industry. London: Croom Helm. 
Schwarz, Leonard. 1999. "English Servants and their Employers during the Eighteenth and Nineteenth Centuries." Economic History Review 52:2.

Scott, Joan Wallach. 1988. "Women in The Making of the English Working Class." W Gender and the Politics of History. Red. Joan Wallach Scott. New York-London: Columbia University Press.

Sewell, William H. 1990. “How Classes are Made: Critical Reflections on E. P. Thompson's Theory of Working-class Formation.” W E. P. Thompson. Critical Perspectives. Red. Harvey J. Kaye i Keith McClelland. Cambridge: Polity Press.

Snell, Keith. 1985. Annals of the Labouring Poor. Social Change and Agrarian England, 1660-1900. Cambridge: Cambridge University Press.

Steedman, Carolyn. 2003. "Servants and their Relationship to the Unconscious." Journal of British Studies 42.

Steedman, Carolyn. 2005. "Poetical Maids and Cooks Who Wrote." Eighteenth-century Studies 39:1.

Carolyn Steedman. 2009. Labours Lost. Domestic Service and the Making of Modern England, Cambridge-New York: Cambridge University Press.

The Parliamentary History of England. 1814. London: T. C. Hansard.

Valenze, Deborah. 1995. The First Industrial Woman. Oxford-New York: Oxford University Press.

Verdon, Nicola. 2002. Rural Women Workers in Nineteenth-Century England. Gender, Work and Wages. Woodbridge: Boydell Press.

Vickery, Amanda. 1998. The Gentleman's Daughter. Women's Lives in Georgian England. New Heaven-London: Yale University Press.

Ward, William R. 1953. The English Land Tax in the Eighteenth Century, Oxford University Press: London.

Wood, Andy. 1999. The Politics of Social Conflict. The Peak Country, 1520-1770. Cambridge: Cambridge University Press.

Wrigley, Edward A. i Roger S. Schofield. 1989. The Population History of England, 1541-1871. A Reconstruction. Cambridge: Cambridge University Press. 
Carolyn Steedman - emerytowana profesor na Wydziale Historycznym Uniwersytetu Warwick.. Autorka licznych publikacji z zakresu historii społecznej Anglii XVIII i XIX wieku, zainteresowana przede wszystkim dziejami proletariatu. Teoretyczka historiografii (jej książka Dust z 2001 roku zawiera eseje na temat archiwów). Ostatnio wydała An Everyday Life of the English Working Class. Work, Self, and Sociability in the Early Ninteenth Century (2013).

DANE ADRESOWE:

History Department

University of Warwick

Coventry CV4 7AL

EMAIL: c.k.steedman@warwick.ac.uk

CYTOWANIE: Steedman, Carolyn. 2017. „Służba i milczenie.” Praktyka Teoretyczna 1(23): 64-83.

DOI: $10.14746 /$ prt.2017.1.3

AUTHOR: Carolyn Steedman

TITLE: On Service and Silences

ABSTRACT: A translated chapter of Carolyn Steedman's book Master and Servant. Love and Labour in the English Industrial Age. This text reconstructs the experience of a 18th-century servant, Phoebe Beatson, on the basis of a diary of John Murgatroyd, her employer. Confronting this testimony with other documents of social life, Steedman constructs a history of a class overlooked by traditional Marxist historiography - female domestic servants.

KEYWORDS: social history, women history, domestic servant, life writing 